\title{
Estimating contributions of pelagic and benthic pathways to consumer production in coupled marine food webs
}

\author{
Jessica I. Duffill Telsnig ${ }^{1}$ (D) | Simon Jennings ${ }^{2,3}$ (D) | Aileen C. Mill ${ }^{1}$ | \\ Nicola D. Walker ${ }^{3}$ | Andrew C. Parnell ${ }^{4}$ Nicholas V. C. Polunin ${ }^{1}$
}

${ }^{1}$ School of Natural and Environmental Sciences, Newcastle University, Newcastle Upon Tyne, UK

${ }^{2}$ International Council for the Exploration of the Sea, Copenhagen V, Denmark

${ }^{3}$ Centre for Environment, Fisheries and Aquaculture Science, Lowestoft, UK

${ }^{4}$ Hamilton Institute, Maynooth University, Maynooth, Ireland

\section{Correspondence}

Jessica I. Duffill Telsnig

j.duffill-telsnig@ncl.ac.uk

Funding information

Natural Environment Research Council, Grant/Award Number: NE/L008718/1; UK Department of Environment, Food and Rural Affairs, Grant/Award Number: project MF1225

Handling Editor: Andrew Jackson

\begin{abstract}
1. Pelagic and benthic systems usually interact, but their dynamics and production rates differ. Such differences influence the distribution, reproductive cycles, growth rates, stability and productivity of the consumers they support. Consumer preferences for, and dependence on, pelagic or benthic production are governed by the availability of these sources of production and consumer life history, distribution, habitat, behavioural ecology, ontogenetic stage and morphology.
\end{abstract}

2. Diet studies may demonstrate the extent to which consumers feed on prey in pelagic or benthic environments. But they do not discriminate benthic production directly supported by phytoplankton from benthic production recycled through detrital pathways. The former will track the dynamics of phytoplankton production more closely than the latter.

3. We develop and apply a new analytical method that uses carbon (C) and sulphur (S) natural abundance stable isotope data to assess the relative contribution of pelagic and benthic pathways to fish consumer production.

4. For 13 species of fish that dominate community biomass in the northern North Sea (estimated $>90 \%$ of total biomass), relative modal use of pelagic pathways ranged from $<25 \%$ to $>85 \%$. Use of both $C$ and $S$ isotopes as opposed to just $C$ reduced uncertainty in relative modal use estimates. Temporal comparisons of relative modal use of pelagic and benthic pathways revealed similar ranking of species dependency over 4 years, but annual variation in relative modal use within species was typically $10 \%-40 \%$.

5. For the total fish consumer biomass in the study region, the $\mathrm{C}$ and $\mathrm{S}$ method linked approximately $70 \%$ and $30 \%$ of biomass to pelagic and benthic pathways, respectively. As well as providing a new method to define consumers' links to pelagic and benthic pathways, our results demonstrate that a substantial proportion of fish biomass, and by inference production, in the northern North Sea is supported by production that has passed through transformations on the seabed.

KEYWORDS

Bayesian mixing model, benthic-pelagic coupling, fish, food webs, marine ecosystems, stable isotope analysis 


\section{1 | INTRODUCTION}

In shallow shelf seas, a large proportion of the detritus produced in the water column will accumulate on the seabed and is consumed by seabed (benthic) fauna (Carstensen, Conley, \& Müller-Karulis, 2003; Kiørboe, Lundsgaard, Olesen, \& Hansen, 1994; Noji, Noji, \& Barthel, 1993; Steele \& Collie, 2005). Phytoplankton primary production is mostly consumed in the water column, although in shallow tidally mixed regions both seabed fauna and zooplankton can be major phytoplankton consumers (Norén, Haamer, \& Lindahl, 1999). In deeper areas, more detritus is broken down by microbial activity in the water column and flux to the seabed is relatively low (Marsay et al., 2015; Suess, 1980). Detritus-based production cycles are typically dampened and attenuated in relation to cycles in primary production. The consequence is that continental shelf consumers rely on one or both of two quite distinct trophic pathways, namely those supported directly by primary production or on those supported by detritus (Moore et al., 2004).

Differences in the production dynamics of pelagic and benthic detrital pathways influence the distribution, reproductive cycles, growth rates, stability and productivity of the consumers they support (Burrel, 1988; Graf, 1992; Hargrave, 1973; Levinton \& Kelaher, 2004; Marcus \& Marcus, 1998). Food web models suggest that the presence of pathways supported by primary production and detritus, dubbed "fast" and "slow," respectively, help to stabilize food webs (McCann, Rasmussen, \& Umbanhowar, 2005). Further, stronger coupling between these pathways may increase food web resilience to human and environmental perturbations (Blanchard, Law, Castle, \& Jennings, 2011).

Various factors may influence species' affiliation to the pathways such as interannual and consumer size-related variation. For example, changes in planktonic productivity can alter the strength of benthic-pelagic coupling (Woodland \& Secor, 2013). Furthermore, small-bodied species and juvenile life stages might depend more on the pelagic pathway due to limited gape size and higher turnover rates (Woodland \& Secor, 2013). Larger individuals with fewer prey size constraints may switch between available prey types, resulting in an increase in trophic reliance on both pathways (Scharf, Juanes, \& Rountree, 2000; Woodland \& Secor, 2013).

Diet data alone will not discriminate benthic production directly supported by phytoplankton from benthic production recycled through seabed pathways, although diet data can be used as inputs to food web models to achieve this if the diet composition of all interacting consumers is well resolved (Polunin \& Pinnegar, 2002). Stable isotope analysis of consumer tissue has been used to measure the extent to which consumers feed on prey from pelagic or benthic environments (Kopp, Lefebvre, Cachera, Villanueva, \& Ernande, 2015; Woodland \& Secor, 2013) and has the potential to discriminate benthic production directly supported by phytoplankton from benthic production recycled through seabed pathways, with the advantage that stable isotope signatures of larger consumers reflect the composition of assimilated diet over several months (Fry, 2006; Michener \& Kaufman, 2007).
Several previous studies of marine pelagic-benthic coupling have shown that consumer $\delta^{13} \mathrm{C}$ can be linked to use of benthic and pelagic pathways (e.g., Davenport \& Bax, 2002; Giraldo et al., 2017; Kopp et al., 2015; Woodland \& Secor, 2013). Species feeding in the pelagic pathway tend to have relatively low $\delta{ }^{13} \mathrm{C}$ values compared to species feeding on benthic material (e.g., Kopp et al., 2015; Le Loc'h, Hily, \& Grall, 2008) owing to differences in the $\delta^{13} \mathrm{C}$ of primary producers, detritus and associated bacteria remineralizing carbon (e.g., Bouillon \& Boschker, 2006; France, 1995; Middelburg, 2014). Diettissue fractionation of ${ }^{13} \mathrm{C}$ is often assumed to be small $(<1 \%$ ), but in practice, for marine fish, fractionation may be higher, with values of $1 \%$ - $2 \%$ more appropriate (Sweeting, Barry, Barnes, Polunin, \& Jennings, 2007).

Sulphur stable isotopes are also expected to provide effective discrimination of marine pelagic and benthic pathways but are only rarely used for this purpose, potentially due to the relatively high cost (Barnes \& Jennings, 2007; Connolly, Guest, Melville, \& Oakes, 2004; Michener \& Kaufman, 2007). Producers predominately deriving sulphur from seawater sulphates such as phytoplankton tend to have $\delta^{34} S$ of $c a$. 19-21\% while producers utilizing sedimentary sulphides will have lower $\delta^{34} \mathrm{~S}$ values (Thode, 1991) by as much as $30 \%$ relative to marine sulphates (Barros, Ostrom, Stricker, \& Wells, 2010; Connolly et al., 2004; Thode, 1991). Sulphur also has the advantage that there is little or no diet-tissue fractionation in $\delta^{34} \mathrm{~S}$ between a fish consumer and diet (0\%०-1\%。 $\delta^{34} \mathrm{~S}$, Barnes \& Jennings, 2007) so errors in assumptions about diet-tissue fractionation will be smaller and they will have a relatively small influence on the estimated contributions of different sources in mixing models (e.g., Parnell, Inger, Bearhop, $\&$ Jackson, 2010), although fractionation may vary more across the entire food chain when differing metabolic pathways are present.

Here, we establish a systematic approach for estimating the contributions of benthic and pelagic pathways to individuals, species and a community. We develop methods that use $\mathrm{C}$ and $\mathrm{S}$ stable isotope data to estimate the relative contributions of predominantly pelagic food chains supported by phytoplankton consumers (dubbed "pelagic pathways") and benthic food chains supported by detrital pathways ("benthic pathways") to the biomass of 15 species of shelf sea fish in the North Sea. Then, we compare the relative contributions of benthic and pelagic pathways as determined from combined analysis of both carbon and sulphur stable isotopes to contribution determined using carbon stable isotopes alone. Finally, we assess interannual and consumer size-related variation in the contributions of benthic and pelagic pathways to biomass and estimate the proportion of total fish community biomass supported by these pathways.

\section{MATERIALS AND METHODS}

\section{1 | Fish sampling and SIA}

Fish were caught in an area from $57.5^{\circ} \mathrm{N}-61.5^{\circ} \mathrm{N}$ to $1^{\circ} \mathrm{W}-4^{\circ} \mathrm{E}$ (mean depth $155 \mathrm{~m}$ ) in August and/or September from 2002 to 2006 during the North Sea English Bottom Trawl Survey, using a Grande Ouverture Verticale bottom-fished otter trawl net with a $20-\mathrm{mm}$ 
cod-end liner which was towed at approximately four knots for $30 \mathrm{~min}$. Fifteen fish species which had the highest rank biomass in the North Sea English Bottom Trawl survey during 2000 and 2001 in the sampling area were caught each year, with an aim to collect up to four individuals from different length classes which spanned the range of total body lengths caught in 2000 and 2001.

Individuals' total body mass was recorded to the nearest $0.1 \mathrm{~g}$ wet mass after blotting to remove surface water, or to $1 \mathrm{~g}$ for larger fishes (typically $>1 \mathrm{~kg}$ ). One to five $\mathrm{cm}^{3}$ of white muscle tissue from the dorsal musculature of each individual was dissected and immediately frozen to $-20^{\circ} \mathrm{C}$. In the laboratory, the frozen stored samples were freeze-dried and ground to a homogeneous fine powder using a pestle and mortar. After processing each sample, all equipment was cleaned. Individual samples were transferred to glass vials prior to weighing into tin capsules for SIA.

The carbon stable isotope composition of samples was determined with a Europa Scientific 20-20 IRMS with a Europa Scientific Roboprep-CN preparation module operated by Iso-Analytical Ltd (Crewe, UK). In the preparation module, two reference samples of Iso-Analytical Standards IA-R014 (powdered bovine liver), IA-R005 (beet sugar) and IA-R045 and IA-R046 (ammonium sulphate) were placed between every four to six-one mg samples of dried fish tissue. The carbon isotope composition of tissue samples was expressed in conventional delta notation $\left(\delta^{13} \mathrm{C}\right)$, relative to the abundance of ${ }^{13} \mathrm{C}$ in Pee Dee Belemnite. Twenty per cent of samples were processed in duplicate for quality control. Standard deviation (SD) for samples within batches for a duplicated pair tended to be slightly higher than for replicates of reference material (but $<0.25 \%$ ), and the 95 th percentile of the overall distribution of absolute differences in each duplicated pair was $0.21 \%$. Experimental precision for all batches of samples was $<0.1 \%$.

The C: $\mathrm{N}$ dry mass ratios of the samples were also determined in the same analysis. When sample C: $\mathrm{N}$ ratios were higher than 3.5 (see Jennings and Cogan (2015) for C: $\mathrm{N}$ values), the $\delta^{13} \mathrm{C}$ values were lipid corrected (Post et al., 2007). Lipid correction used eq. 1 in Sweeting, Polunin, and Jennings (2006), which produces estimates of $\delta^{13} \mathrm{C}$ comparable with those based on chemical lipid extraction for fish tissue (Sweeting et al., 2006).

For ${ }^{34} \mathrm{~S}$ analysis, tin capsules containing 2-mg dried fish tissue or reference material plus $4 \mathrm{mg}$ vanadium pentoxide were processed with an automatic sampler coupled to a Europa Scientific 20-20 isotope ratio mass spectrometer operated by Iso-Analytical Limited (Crewe, UK). The reference material used was IA-R036 (Iso-Analytical working standard barium sulphate, $\delta^{34} \mathrm{~S}_{\mathrm{V} \text {-CDT }}+20.74 \%$ ) calibrated and traceable to NBS-127 (barium sulphate, $\delta^{34} \mathrm{~S}_{\mathrm{V} \text {-CDT }}+20.3 \%$ ). Two capsules containing organic standards, with a composition closer to fish tissue than the inorganic standards, were run after every five tissue samples. The organic standards were IA-R036 and IA-R027 (Iso-Analytical working standard whale baleen, $\delta^{34} \mathrm{~S}_{\mathrm{V}-\mathrm{CDT}}+16.3 \%$ ). Analytical precision was good (SD of organic standards $<0.25 \%$ ). All results are presented in conventional per mil notation (\%) in relation to the primary ${ }^{34} \mathrm{~S}$ isotope standard V-CDT (troilite of the Canyon Diablo meteorite).
Two source indicator species were selected, to characterize the isotopic composition associated with high dependence on the pelagic or high dependence on the benthic pathway, respectively. The affiliation of the remaining 13 species in the community to these pathways was expressed in relation to the dependence of the source indicator species. Each source indicator species was initially identified using a combination of diet and stable isotope data. Diet data were obtained from the Integrated Database and Portal for Fish Stomach Records (DAPSTOM, Pinnegar, 2014a, 2014b). All available diet records for the Irish, Celtic, North Sea and English Channel were used to classify the prey of each fish species in the size ranges sampled in this study. The prey of each fish species were classified as "benthic," "pelagic" or "unknown" based on position in the water column (Supporting Information Table S1). Benthic prey were assumed to be all species or groups living on or in the seabed which were more likely to consume material cycled through benthic pathways. Pelagic prey were assumed to be all species or groups living anywhere else in the water column, which were more likely to be supported by food chains based on living phytoplankton. "Unknown" prey included prey items which were unidentifiable (e.g., partially digested), non-living items (e.g., rock or sand) or items for which the ecology is not sufficiently understood. Mackerel Scomber scombrus Linnaeus, 1758 had consumed the highest proportion of pelagic items by number, while plaice Pleuronectes platessa Linnaeus, 1758 and lemon sole Microstomus kitt (Walbaum, 1792) had consumed the highest proportion of benthic items (Supporting Information Table S1). Calculations were based on prey number because prey mass data were not available. P. platessa and M. kitt had consumed 99.1 and $99.2 \%$ benthic prey, respectively, but given that the mean $\delta^{13} \mathrm{C}$ of $P$. platessa was less negative than the mean for M. kitt ( $-16.9 \%$ vs. $-17.9 \%$ ), and that this difference would have held even after accounting for the small differences in trophic level between these species (Jennings \& van der Molen, 2015), we took plaice as the source indicator species. To test the sensitivities of source indicator species and to assess whether results may be affected by the migratory movements of mackerel outside the North Sea, supplementary analyses were conducted using North Sea herring Clupea harengus Linnaeus, 1758 as a source indicator species for pelagic production (Supporting Information Figure S1).

$\delta^{13} \mathrm{C}$ and $\delta^{34} \mathrm{~S}$ isotopic values of fish consumers were also adjusted to a "common" trophic level (TL) to account for small trophic level differences which might influence the isotopic values of individuals, independent of any contribution of benthic and pelagic pathways. Median TL estimates (Jennings \& van der Molen, 2015) were adjusted for trophic fractionation as follows: $\delta^{13} \mathrm{C}_{\text {corrected }}=\delta^{13} \mathrm{C}_{\text {actual }}+\left(-1.74\left(\mathrm{TL}_{\text {actual }}-4.5\right)\right)$ and $\delta^{34} \mathrm{~S}_{\text {corrected }}=\delta^{34} \mathrm{~S}_{\text {actual }}+\left(-0.45\left(\mathrm{TL}_{\text {actual }}-4.5\right)\right)$ where $\mathrm{TL}_{\text {actual }}-4.5$ generates an arbitrary common baseline TL that is close to the mean for all sampled individuals and the multipliers represent the mean trophic fractionation of each isotope in teleost fish as reported in Barnes, Sweeting, Jennings, Barry, and Polunin (2007) and Sweeting, Barry, Polunin, and Jennings (2007), respectively. Further analyses were run both with TL corrected and uncorrected isotopic values (TL uncorrected results in Supplementary material).

Biomass estimates were based on numbers-at-length recorded in the International Bottom Trawl Survey in the area $0^{\circ}-4^{\circ} \mathrm{E}$ and 
TAB LE 1 Estimated relative contribution of pelagic pathways (modal SC and C estimates) to total biomass (tonnes) in the sampling area (estimated contribution to pelagic pathway by mackerel and plaice assumed to be 0.99 and 0.01 , respectively)

\begin{tabular}{|c|c|c|c|c|c|}
\hline Species name & Common name & Authority & $\begin{array}{l}\text { Species' } \\
\text { biomass (t) }\end{array}$ & $\begin{array}{l}\text { Biomass "pelagic" (t) } \\
\delta^{34} S \& \delta^{13} \mathrm{C}\end{array}$ & $\begin{array}{l}\text { Biomass } \\
\text { "pelagic" }(t) \delta^{13} C\end{array}$ \\
\hline Scomber scombrus & Mackerel & Linnaeus, 1758 & 324,104 & 320,863 & 320,863 \\
\hline Trisopterus esmarkii & Norway pout & (Nilsson, 1855) & 144,739 & 110,586 & 88,489 \\
\hline Pollachius virens & Saithe & (Linnaeus, 1758) & $1,460,296$ & 958,157 & 752,536 \\
\hline Eutrigla gurnardus & Grey gurnard & (Linnaeus, 1758) & 99,286 & 60,872 & 53,974 \\
\hline $\begin{array}{l}\text { Melanogrammus } \\
\text { aeglefinus }\end{array}$ & Haddock & (Linnaeus, 1758) & 261,692 & 158,852 & 138,752 \\
\hline $\begin{array}{l}\text { Hippoglossoides } \\
\text { platessoides }\end{array}$ & Long rough dab & (Fabricius, 1780) & 30,328 & 17,732 & 13,971 \\
\hline Merlangius merlangus & Whiting & (Linnaeus, 1758) & 90,294 & 28,094 & 24,080 \\
\hline Lophius piscatorius & Anglerfish & Linnaeus, 1758 & 26,976 & 8,218 & 6,435 \\
\hline Gadus morhua & Cod & Linnaeus, 1758 & 26,554 & 7,151 & 6,513 \\
\hline \multirow[t]{2}{*}{ Pleuronectes platessa } & Plaice & Linnaeus, 1758 & 7,317 & 73 & 73 \\
\hline & & (Totals) & $(3,191,700)$ & $(2,268,470)$ & $(189,420)$ \\
\hline
\end{tabular}

$56^{\circ}-62^{\circ} \mathrm{N}$ in 2006 . Catch numbers by species and length per hour of trawling were converted to mean numerical density per ICES statistical rectangle using information on tow distance, gear dimensions and gear efficiency (Walker, Maxwell, Le Quesne, \& Jennings, 2017). For each species, mean numerical density by length was converted to total numbers-at-length for the whole study area by multiplying the numerical density in each rectangle by the area of the rectangle and summing over all rectangles. Estimates of biomass by species and length were then obtained by converting individual lengths $(L, c m)$ to individual weights $(W, g)$ using the relationship $W=a L^{b}$, with parameters $a$ and $b$ from Silva, Ellis, and Ayers (2013), and multiplying individual weights by numbers-at-length.

\section{2 | Mixing models}

Two end-member Bayesian mixing models were used to estimate the contribution of the pelagic and benthic pathways to fish biomass. Both models were based on simmr (Parnell, 2016), one using $\delta^{13} \mathrm{C}$ and $\delta^{34} S$ as inputs and one using only $\delta^{13} \mathrm{C}$.

The model equations were eqs. 1-4 in Parnell et al. (2013). The source values $s_{j k}$ are assumed to be normally distributed based on the mean and $S D$ of the stable isotopic composition of the two source indicator species (Supporting Information Figure S2). A prior is given for the dietary proportions of each individual $i$ on source $k$ (denoted $p_{i k}$ ) based on the centralized log-ratio normal distribution. The residual SD (denoted $\sigma_{i j}$ for isotope $j$ ) was given a uniform prior distribution from 0 to 100. Trophic fractionation factors or concentration dependencies were not included.
Individuals were grouped by species and 100,000 iterations were run to generate a posterior probability density based on estimated contributions of the pelagic pathway to biomass. The mixing model using $\delta^{13} \mathrm{C}$ and $\delta^{34} \mathrm{~S}$ data was run for the 2006 data and the model using just $\delta^{13} \mathrm{C}$ was run for every year from 2002 to 2006 . Output comprised estimates of modal and $50 \%$ credible intervals of the posterior distribution.

To examine the effects of body size (mass) within species and year on the contribution of the pelagic pathway, the two end-member Bayesian mixing model described above was adapted to include covariates. The model was developed in R using packages R2JAGS (Su \& Yajima, 2015) and PLYR (Wickham, 2011). The model was run grouping all species together to examine the overall effect of mass and year. Species were also separated to examine the effect of mass and year on individual species. One million iterations were run for all individuals and 100,000 iterations for individual species. Output comprised estimates of modal and $50 \%$ credible intervals of the contribution of the pelagic pathway in centralized log-ratio transformed space, a value for convergence of the model for all parameters $(\hat{R})$ and an estimate for the amount of variation not explained by the parameters $(\sigma)$. We only present results for models where the $\hat{R}$ value was close to 1 , indicating model convergence has occurred.

\section{3 | RESULTS}

Estimates of the relative contributions of pelagic and benthic pathways to fish biomass in 2006, as generated with combined $\delta^{34} \mathrm{~S}$ and $\delta^{13} \mathrm{C}$ (hereafter $\mathrm{SC}$ ) analysis, were more precise than those 
FIGURE 1 The estimated relative contribution of the pelagic pathway to fish biomass by species in 2006 using both $\delta^{34} \mathrm{~S}$ and $\delta^{13} \mathrm{C}$ isotopes (SC) or just $\delta^{13} \mathrm{C}(\mathrm{C})$. Species are ranked based on SC estimates. Points show the mode and bars the $50 \%$ credible intervals of the posterior distribution

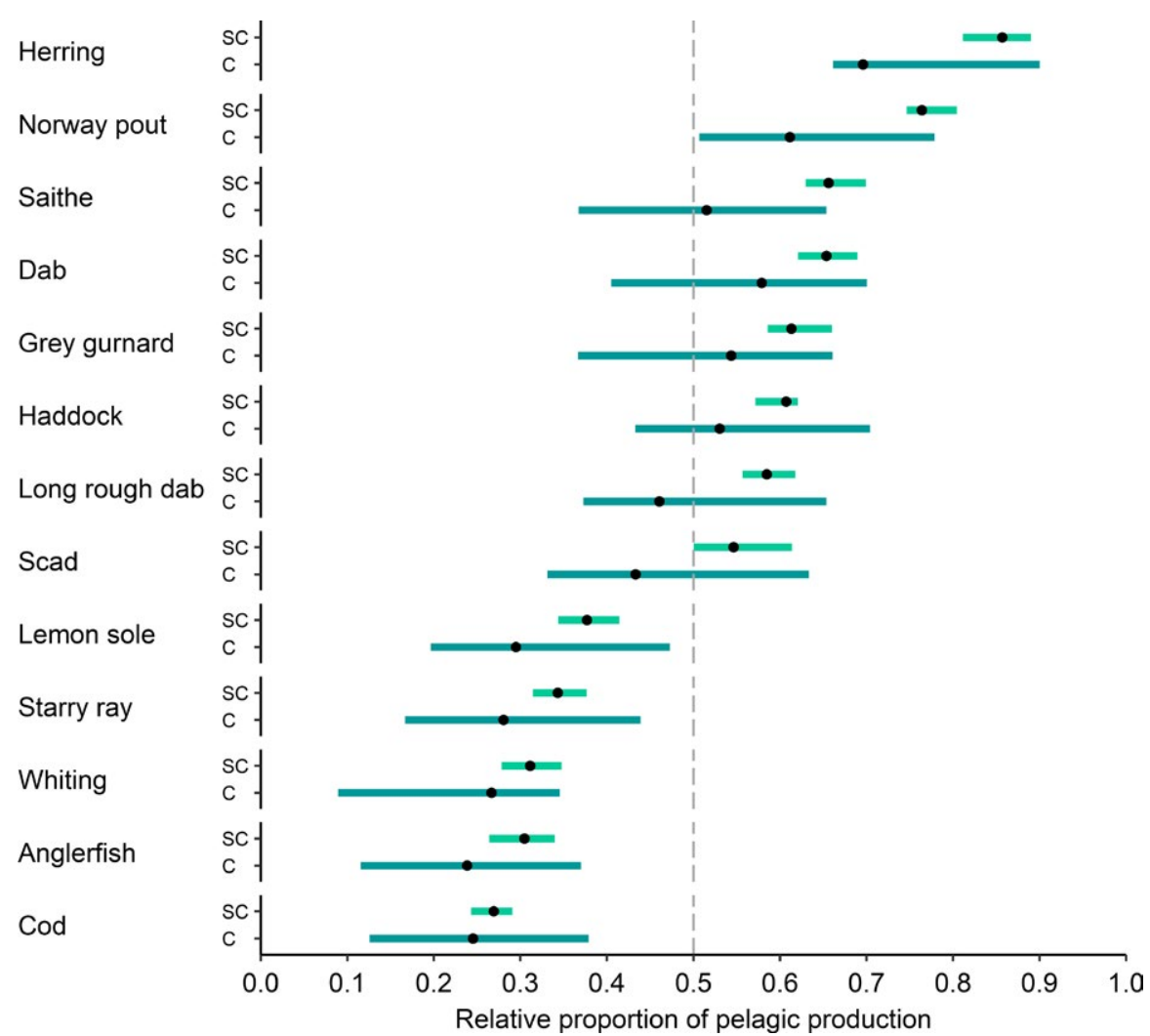

generated with $\delta^{13} \mathrm{C}(\mathrm{C})$ alone (Figure 1). However, the rank-order relative contribution of pelagic pathways, based on relative modal importance of the pelagic pathway, was almost identical (Figure 1), with a Spearman rank correlation between modes of the credible intervals of 0.96 , and 0.90 and 0.93 correlations for the lower and upper bounds of the $50 \%$ credible interval. Contributions of the pathways are described as relative because they are expressed in relation to the assumed pelagic contributions of mackerel and plaice, which were taken as 0.99 and 0.01 in the absence of data or a mechanism to define absolute estimates.

The overall relative contributions of pelagic pathways to fish biomass in 2006, based on the relative modal values from the SC and C models and the estimates of fish biomass, were $71 \%$ and $59 \%$, respectively (Table 1). This result implies that $29 \%$ or $41 \%$ of biomass was sustained by energy that had cycled through benthic detrital pathways. C. harengus and saithe Pollachius virens (Linnaeus, 1758), the most abundant species in the community, had $86 \%$ and $66 \%$ pelagic affiliations respectively (Figure $1, \mathrm{SC}$ estimates).

In 2006, based on both SC and C, there was a marked decrease in pelagic affiliation and an increase in benthic affiliation with body mass for the community as a whole. The larger value of $\sigma$ for $\mathrm{C}$ demonstrated that more variation was unexplained when $\mathrm{S}$ data were not included in the analyses (Table 2).

Interannual changes in the relative contribution of pelagic pathways to species' biomass, as determined with $\delta^{13} \mathrm{C}$ data, were modest (Figure 2), and correlations between years for the relative modal contributions of pelagic pathways were always $>0.57$ (Table 3). The Bayesian model with a "year" covariate reinforced this result, showing only weak year effects (Table 4). The weak year effect detected was negative (mode, -0.04), implying a fall in the relative proportion of biomass supported by pelagic pathways from 2002 to 2006.

The effect of body mass on the relative use of the pelagic pathway by the whole fish community was negative and much stronger than the effect of year (Table 4). The high $\sigma$ indicates that much of the variation in relative use of the pelagic pathway is unexplained by year or mass.

The effects of year and body mass on the relative contribution of the pelagic pathway (Figure 3) or benthic pathway (Supporting Information Figure S3) to individual species' biomass from 2002 to 2006 were species dependent. The negative relationship between mass and the relative use of the pelagic pathway was especially strong for whiting Merlangius merlangus (Linnaeus, 1758), dab Limanda limanda (Linnaeus, 1758), starry ray Amblyraja radiata (Donovan, 1808) and M. kitt. Conversely, body mass was positively related to the relative use of the pelagic pathway for $C$. harengus and grey gurnard Eutrigla gurnardus (Linnaeus, 1758).

\section{DISCUSSION}

When attempting to understand the significance of pelagic and benthic food web pathways, our method provides an important complement to diet studies. This is because it characterizes the extent to which production is channelled through pelagic or benthic systems as opposed to focusing on the habitat choice of prey or where those prey are consumed. Thus, our results show that even those 
TAB LE 2 Effects of body mass on use of pelagic (p) and benthic (b) pathways in the North Sea during 2006 (mode and $50 \%$ credible intervals). Positive values indicate increasing reliance on the relevant pathway. $\sigma$ is an estimate for the amount of variation not explained by the parameters

\begin{tabular}{|c|c|c|c|c|c|c|}
\hline & \multicolumn{3}{|c|}{$\delta^{13} C \& \delta^{34} S$} & \multicolumn{3}{|l|}{$\delta^{13} \mathrm{C}$} \\
\hline & $25 \%$ & Mode & $75 \%$ & $25 \%$ & Mode & $75 \%$ \\
\hline Body mass [b] & 0.17 & 0.69 & 1.20 & 0.15 & 0.67 & 1.18 \\
\hline$\sigma$ & 0.90 & 0.92 & 0.93 & 1.11 & 1.14 & 1.17 \\
\hline
\end{tabular}

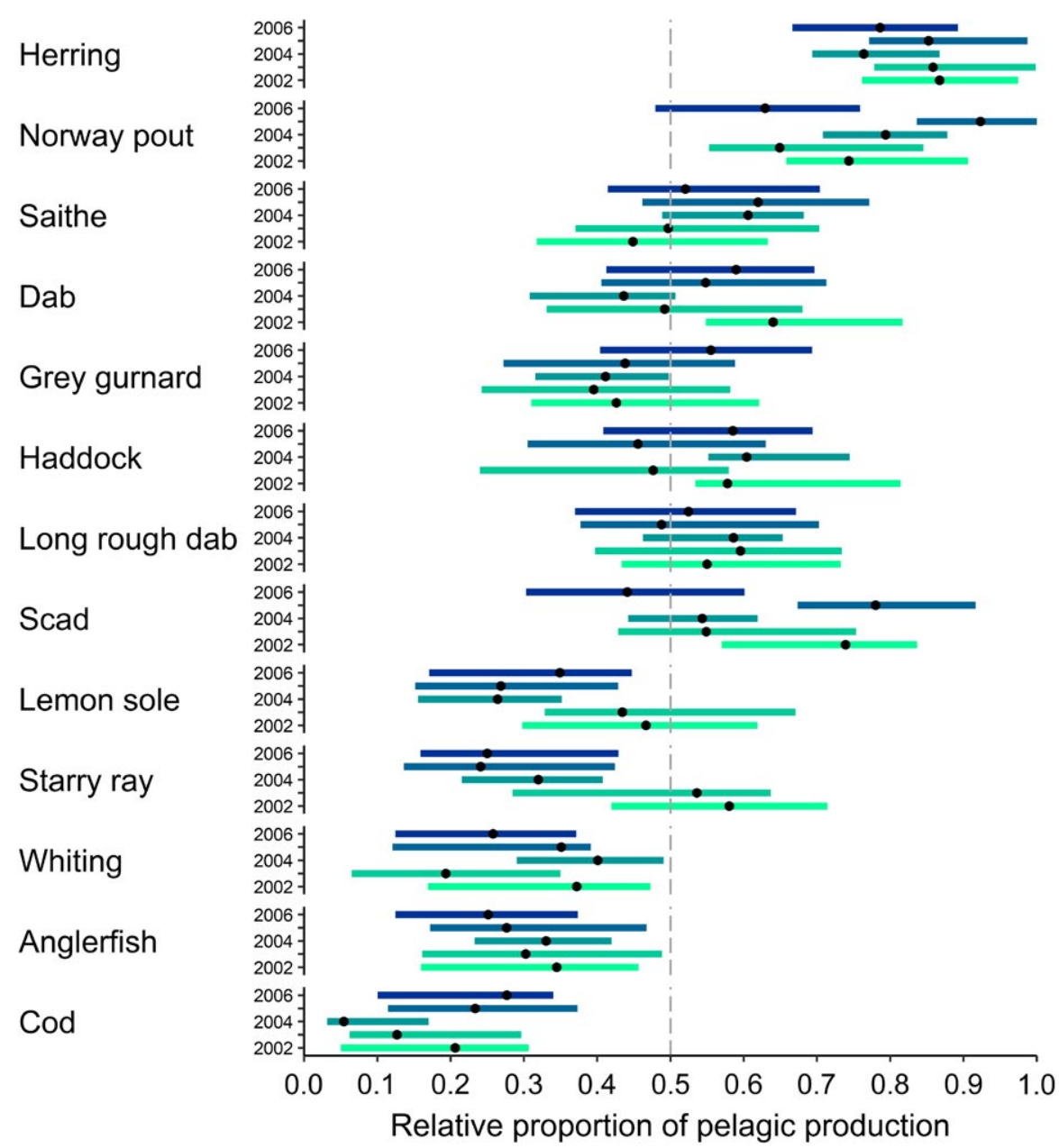

FIGURE 2 The estimated relative contribution of the pelagic pathway to fish biomass by species from 2002 to 2006 based on $\delta^{13} \mathrm{C}$ analysis. Points show the mode and bars the $50 \%$ credible intervals of the posterior distribution
TABLE 3 Correlations, between years, of relative modal contributions of pelagic pathways to species' biomass

\begin{tabular}{llllll} 
Year & 2002 & 2003 & 2004 & 2005 & 2006 \\
2002 & - & 0.88 & 0.65 & 0.73 & 0.63 \\
2003 & & - & 0.74 & 0.76 & 0.57 \\
2004 & & & - & 0.93 & 0.79 \\
2005 & & & & - & 0.78 \\
\hline 2006 & & & & & - \\
\hline
\end{tabular}

species feeding on the seabed rely significantly on pelagic production, probably because a proportion of their bottom-living prey are feeding directly on phytoplankton (Jumars, Dorgan, \& Lindsay, 2015; Lehane \& Davenport, 2002; Vedel, 1998). Diel vertical migration
TAB LE 4 The effect of body mass and year on the relative contribution of pelagic (p) and benthic (b) pathways to North Sea fish biomass from 2002 to 2006 (mode and 50\% credible intervals). Positive values indicate increasing reliance on the relevant pathway

\begin{tabular}{lccc} 
& $25 \%$ & Mode & 75\% \\
\hline Body mass [p] & -3.49 & -2.93 & -2.37 \\
\hline Body mass [b] & 2.38 & 2.93 & 3.48 \\
\hline Year [p] & -0.50 & -0.04 & 0.45 \\
\hline Year [b] & -0.42 & 0.05 & 0.54 \\
\hline$\sigma$ & 1.30 & 1.32 & 1.33 \\
\hline
\end{tabular}

of zooplankton may also play a significant role in the channelling of pelagic production to benthic consumers (Ringelberg, 2010). Conventional diet studies describing the extent to which consumers 
FIGURE 3 Effects of year (top) and body mass (bottom) on relative contributions of the pelagic pathway to species' biomass from 2002-2006. Positive values indicate increasing reliance on the pelagic pathway with increasing body mass or year. Points show the mode and bars the $50 \%$ credible intervals. Modal values of $\sigma$ ranged from 0.8 to 1.37 across species

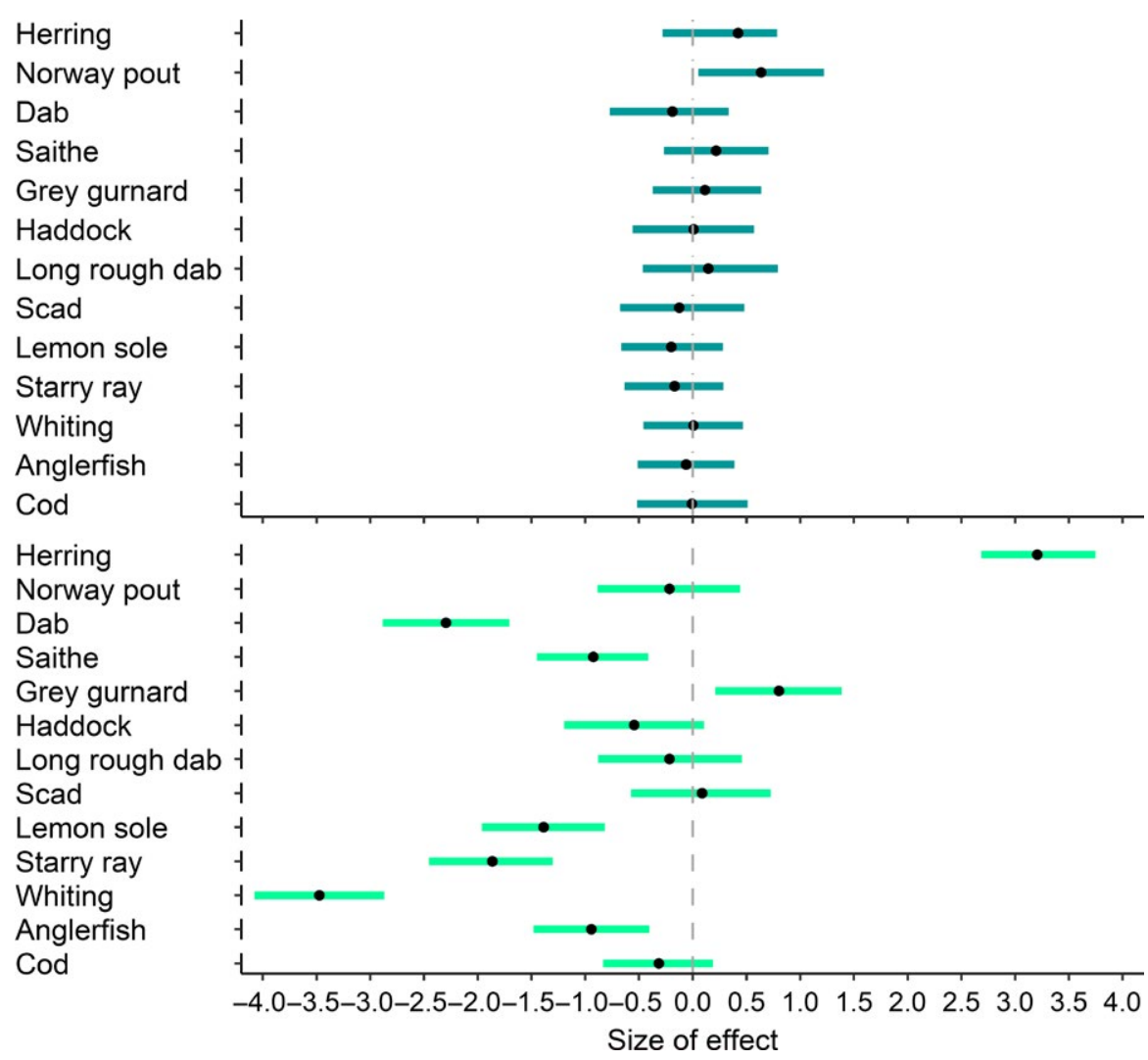

feed on prey found in pelagic or benthic environments may not indicate the extent to which consumers are supported by food chains supplied by phytoplankton grazing or benthic detrital chains. This is because some benthic fauna gain a substantial proportion of their energy from grazing pelagic phytoplankton or zooplankton in shallow shelf seas (Jumars et al., 2015; Lehane \& Davenport, 2002; Vedel, 1998) and because invertebrates and fish accessible to predators feeding in the water column may feed extensively on benthic detritus and food chains supported by benthic detritus (Jumars, 2007; Marcus \& Marcus, 1998; Mauchline, 1980). Nektobenthic organisms, for example, are well recognized as important prey of pelagic fishes such as C. harengus (Casini, Cardinale, \& Arrhenius, 2004) as well as bottom-dwelling fishes (Mauchline, 1982).

Results implied that the use of the pelagic feeding pathway by C. harengus increased with body mass. This was counter to the trend for other species. Previous studies of the trophic role of $C$. harengus based on nitrogen stable isotope analysis have implied that trophic level consistently decreases with body mass, falling by almost one trophic level as mass increases from 30 to $300 \mathrm{~g}$ (Jennings, D'Oliveira, \& Warr, 2007). There are at least two potential drivers of the apparent increase in use of the pelagic pathway and decrease in trophic level: first, interactions between the spatial distributions of base $\delta^{13} \mathrm{C}$ in the North Sea and age-specific $C$. harengus distributions and second, real changes in $C$. harengus feeding ecology with age.

In relation to the first driver, Bierman et al. (2010) described the spawning origin of $C$. harengus caught in the central and northern North Sea in summers of 2004-2007. At the latitudes of our sampling stations, autumn spawning C. harengus (Banks, Buchan and
Shetland herring) tended to be most abundant, but winter spawners from the southern North Sea (Downs herring) are also present. Autumn spawners spawn in several inshore areas to the west of the study region and young $C$. harengus tend to stay in relatively shallow water $(<100 \mathrm{~m})$ for at least their first year (typically weighing $<30 \mathrm{~g}$ ). With age, they move further offshore, predominantly appearing in the study region at an age of 2 or 3 yr (typically 120-140 g). Winter spawners spend their first year in the southern and central North Sea. The spatial distribution of one measure of base $\delta^{13} \mathrm{C}$ in the North Sea (Barnes, Jennings, \& Barry, 2009a, 2009b) varied from -17.6 to $-18 \%$ in the study region, compared with -17.4 to $-17.8 \%$ 。 in the inshore areas used by young autumn spawning $C$. harengus and -16 to $-17 \%$ in the southern areas used by young winter spawners and adult winter spawners during their migrations. Consequently, autumn spawning $C$. harengus that have just recruited to the study region may have marginally higher $\delta^{13} \mathrm{C}$ than older $\mathrm{C}$. harengus, but the effect on estimates of the relative proportion of pelagic production and trophic level is likely to be small. For winter spawning C. harengus, the effect may be much larger, and given interannual variation in the extent of mixing of autumn and winter spawners in the central North Sea (Bierman et al., 2010), the effects of movement on an apparent increase in use of the pelagic pathway and decrease in trophic level cannot be discounted.

In relation to the effects of real changes in feeding ecology, the increase in the use of the pelagic pathway and decrease in trophic level with body mass in $C$. harengus may reflect an increase in the prevalence of filter feeding with body mass. We are not aware that such a shift has been studied or documented with diet data (Petitgas, 
2010), but methods for examining gut contents as used in existing diet studies are unlikely to record phytoplankton feeding effectively. For other clupeid species, where patterns of direct phytoplankton consumption have been a research focus, an increase in phytoplankton feeding and decrease in trophic level with body size result from increased filter feeding and decreased particulate feeding. In sardine Sardina pilchardus (Walbaum, 1792), for example, Bode, Carrera, and Lens (2003) demonstrated that $\delta^{15} \mathrm{~N}$ of $S$. pilchardus $\geq 18 \mathrm{~cm}$ in total length fell with body size. This reduction in $\delta^{15} \mathrm{~N}$ is consistent with a decrease in trophic level (Bode et al., 2007), which would result from increased feeding on phytoplankton by larger fish in cases when phytoplankton was abundant (Garrido, Marçalo, Zwolinski, \& Van der Lingen, 2007). Consumption of phytoplankton by filter feeding S. pilchardus may be considerable when large phytoplankton is abundant. For example, chain-forming diatoms may account for $99 \%$ of prey ingested by S. pilchardus during spring upwelling events off the Portuguese coast (Garrido, 2003). Despite the likely increase in the prevalence of phytoplankton in the diets of filter feeding fish, the absolute trophic levels of S. pilchardus (Bode et al., 2017) and C. harengus (Jennings \& van der Molen, 2015) both imply that zooplankton still contribute substantially to assimilated diet of larger fish. In future, studies to quantify the role of phytoplankton in ingested and assimilated diet of herring would be valuable. This is because confirmation of reductions in trophic level and increases in direct use of phytoplankton with body size would substantially alter our understanding of the structure and function of pelagic food webs in regions where herring are abundant. These regions include our study sites (Table 1) and the North Sea more widely (Sparholt, 1990).

Our analytical framework provides relative measures of the use of pelagic and benthic pathways. To generate these measures, we assumed $99 \%$ use of the pelagic and benthic pathways by S. scombrus and P. platessa, respectively (the source indicator species). While it is reasonable to assume from diet and stable isotope evidence that S. scombrus primarily use the pelagic pathway and P. platessa primarily use the benthic pathway, their absolute use of either pathway is not known. For these reasons, we always refer to "relative" use of a pathway. However, we do not expect absolute use of the pathways to differ markedly from our $99 \%$ assumptions given that mean depth in the study region was $170 \mathrm{~m}$. Giraldo et al. (2017), for example, used $\mathrm{C}$ and $\mathrm{N}$ stable isotopes to demonstrate that coupling between pelagic and benthic systems decreases markedly with depth on another part of the northern European continental shelf. At $100 \mathrm{~m}$ depth, the maximum depth at which they modelled results, the use of the benthic pathway by fishes feeding on the seabed was approximately $85 \%$ and the use of the pelagic pathway by pelagic piscivores was approximately $95 \%$. Given P. platessa and S. scombrus are members of these feeding groups, and given that relationships between depth and use of pelagic or benthic pathways were still positive at $100 \mathrm{~m}$ in the study of Giraldo et al. (2017), it is likely that the assumed $99 \%$ use of each pathway at a mean depth of $170 \mathrm{~m}$ would be within a few per cent of the true value (e.g., perhaps within $2 \%$ for the pelagic pathway and $10 \%$ for the benthic pathway). Thus, the errors introduced by estimating pelagic or benthic use for the source indicator species are small in relation to the uncertainties in use of the pathways addressed and expressed in the Bayesian analyses. Since absolute use of the pelagic or benthic pathway by source indicator species is not known, estimates of use of the pelagic or benthic pathway by other species are tied to these. Consequently, conclusions about small changes in the use of pathways by these species through time may also be interpreted as changes in the use of pathways among species and may not indicate absolute changes in reliance on pelagic or benthic pathways at a system level.

In future, it would be desirable to develop the stable isotope methods to provide absolute estimates of pelagic or benthic affiliation in the study region. This would require the identification of species that are specialist feeders on phytoplankton and benthic detritus-based food chains, respectively, and then to sample them with sufficient frequency to account for the short-term isotope dynamics which are evident in smaller individuals with fast turnover times (Kürten, Painting, Struck, Polunin, \& Middelburg, 2013; Wainright \& Fry, 1994). An alternative is to simulate the seasonal dynamics of $\delta^{34} \mathrm{~S}$ and $\delta^{13} \mathrm{C}$ in phytoplankton and benthic detritus with models to generate time-integrated estimates of source $\delta^{34} \mathrm{~S}$ and $\delta^{13} \mathrm{C}$, as now being attempted for $\delta^{13} \mathrm{C}$ (Magozzi, Yool, Vander Zanden, Wunder, \& Trueman, 2017) and widely adopted already for $\delta^{15} \mathrm{~N}$ by biological oceanographers (Somes et al., 2010).

The use of two end-member Bayesian mixing models with both CS and C stable isotope data provided comparable estimates of the relative use of pelagic and benthic pathways by marine fishes in the North Sea, although uncertainty around modal estimates increased when $C$ was used in isolation. The effects of adding $S$ to the mixing model on the precision of the result were unsurprising given the low trophic fractionation of S (which would have minimized any variance in estimates of the relative use of pelagic and benthic pathways introduced by inaccurate estimates of trophic level) and the large and consistent differences between $\delta^{34} \mathrm{~S}$ of sulphates and sulphides (Barros et al., 2010; Connolly et al., 2004; Thode, 1991). Our conclusion that $\mathrm{S}$ led to more precise estimates of source contributions was consistent with the results of Connolly et al. (2004), where a meta-analysis was used to assess the extent to which $\delta^{15} \mathrm{~N}, \delta^{13} \mathrm{C}$ and $\delta^{34} \mathrm{~S}$ distinguished sources in estuarine and marine food webs and affected the precision of estimates of source contributions to consumers. When mixing models included both $\mathrm{C}$ and $\mathrm{S}$, the credible intervals around mean estimates of source contributions to consumers were reduced, even though $\mathrm{S}$ showed greater within source variability than $C$.

Relative use of pelagic and benthic pathways varied considerably among species, but more than two-thirds of the biomass in the total fish community was linked to food chains that were ultimately supported primarily by direct phytoplankton grazing rather than production recycled through benthic detrital pathways. Within the community, differences in the relative use of pelagic and benthic pathways by different species were largely consistent from year to year, despite potential fluctuations in planktonic activity, likely reflecting the relatively constrained habitats and diets of most species (Heessen, Daan, \& Ellis, 2015) as constrained by morphology 
and other species' characteristics determined on evolutionary timescales (Reecht, Rochet, Trenkel, Jennings, \& Pinnegar, 2013).

Approximately $30 \%$ of total consumer biomass was linked to the benthic pathway, demonstrating that a substantial proportion of fish biomass, and by inference production, in the northern North Sea is supported by production that has passed through transformations on the seabed. All sampled species appear to use both pelagic and benthic pathways to some extent. Accessing both pathways is likely to provide a more resilient feeding strategy than reliance on one or other pathway because detrital-based production cycles are typically dampened and attenuated in relation to cycles in primary production and, together, these out of phase cycles will stabilize temporal variance in total production (Mussap \& Zavatarelli, 2017; Ruardij \& Van Raaphorst, 1995) and thus food supply to a range of consumers (Darnell, 1961; Kopp et al., 2015). Further, there is strong theoretical evidence to suggest that the presence and use of pathways supported by both primary production and detritus stabilize food webs (McCann et al., 2005) and coupling between these pathways may increase food web resilience to human and environmental perturbations (Blanchard et al., 2011).

\section{ACKNOWLEDGEMENTS}

This research was funded by NERC (NE/L008718/1) and the UK Department of Environment, Food and Rural Affairs (project MF1225 Integration of environmental and fisheries management). We thank many staff at the International Council of the Exploration of the Sea (ICES), the Centre for Environment, Fisheries and Aquaculture Science (Cefas) and Iso-Analytical Ltd for collection and provision of data and processing of samples. We thank Mark Dickey-Collas and Pierre Petitgas for sharing insights into the trophic ecology of herring and other clupeid fishes and proposing explanations for the increase in pelagic affinity with body size.

\section{AUTHORS' CONTRIBUTIONS}

J.I.D.T., S.J., N.V.C.P. and A.C.M. conceived the ideas and designed the methodology; A.C.P. designed the mixing models used to analyse the data; J.I.D.T., N.D.W. and S.J. extracted and analysed the data and J.I.D.T. led the writing of the manuscript. All authors contributed critically to the drafts and gave final approval for publication.

\section{DATA ACCESSIBILITY}

Data used in this study are available from the following sources: $\delta^{34} \mathrm{~S}$ for fish consumers is available from the Dryad Digital Repository: https://doi.org/10.5061/dryad.j6m2267 (Duffill Telsnig et al., 2018). $\delta^{13} \mathrm{C}$ and $\mathrm{C}: \mathrm{N}$ for fish consumers is from Jennings and Cogan (2015). Fish survey length and catch rate data are available from ICES (2016). $\delta^{13} \mathrm{C}$ scallop data are available from the Dryad Digital Repository: https://doi.org/10.5061/dryad.sj4fn (Barnes et al., 2009b). Fish stomach contents are available from Pinnegar (2014a, 2014b). Trophic level estimates for fish consumers are available from
Jennings and van der Molen (2015). Code used to create the Bayesian mixing models is available from Zenodo: https://doi.org/10.5281/zenodo.1476659 (Telsnig, 2018).

\section{ORCID}

Jessica I. Duffill Telsnig (iD https://orcid.org/0000-0002-7663-8081 Simon Jennings (iD http://orcid.org/0000-0002-2390-7225

Nicholas V. C. Polunin (iD http://orcid.org/0000-0002-1480-8794

\section{REFERENCES}

Barnes, C., \& Jennings, S. (2007). Effect of temperature, ration, body size and age on sulphur isotope fractionation in fish. Rapid Communications in Mass Spectrometry, 21(8), 1461-1467. https://doi. org $/ 10.1002 / \mathrm{rcm} .2982$

Barnes, C., Jennings, S., \& Barry, J. T. (2009a). Environmental correlates of large-scale spatial variation in the $\mathrm{d} 13 \mathrm{C}$ of marine animals. Estuarine, Coastal and Shelf Science, 81(3), 368-374. https://doi.org/10.1016/j. ecss.2008.11.011

Barnes, C., Jennings, S., \& Barry, J. T. (2009b). Data from: Environmental correlates of large-scale spatial variation in the $\delta^{13} \mathrm{C}$ of marine animals (and related published studies of carbon and nitrogen isotopic baselines). Dryad Digital Repository, https://doi.org/10.5061/dryad.sj4fn

Barnes, C., Sweeting, C. J., Jennings, S., Barry, J. T., \& Polunin, N. V. C. (2007). Effect of temperature and ration size on carbon and nitrogen stable isotope trophic fractionation. Functional Ecology, 21(2), 356362. https://doi.org/10.1111/j.1365-2435.2006.01224.x

Barros, N. B., Ostrom, P. H., Stricker, C. A., \& Wells, R. S. (2010). Stable isotopes differentiate bottlenose dolphins off west-central Florida. Marine Mammal Science, 26(2), 324-336. https://doi. org/10.1111/j.1748-7692.2009.00315.x

Bierman, S. M., Dickey-Collas, M., van Damme, C. J. G., van Overzee, H. M. J., Pennock-Vos, M. G., Tribuhl, S. V., \& Clausen, L. A. W. (2010). Between-year variability in the mixing of North Sea herring spawning components leads to pronounced variation in the composition of the catch. ICES Journal of Marine Science, 67, 885-896. https://doi. org/10.1093/icesjms/fsp300

Blanchard, J. L., Law, R., Castle, M. D., \& Jennings, S. (2011). Coupled energy pathways and the resilience of size-structured food webs. Theoretical Ecology, 4(3), 289-300. https://doi.org/10.1007/ s12080-010-0078-9

Bode, A., Alvarez-Ossorio, M. T., Cunha, M. E., Garrido, S., Peleteiro, J. B., Porteiro, C., ... Varela, M. (2007). Stable nitrogen isotope studies of the pelagic food web on the Atlantic shelf of the Iberian Peninsula. Progress in Oceanography, 74(2-3), 115-131. https://doi. org/10.1016/j.pocean.2007.04.005

Bode, A., Carrera, P., González-Nuevo, G., Nogueira, E., Riveiro, I., \& Santos, M. B. (2017). A trophic index for sardine (Sardina pilchardus) and its relationship to population abundance in the southern Bay of Biscay and adjacent waters of the NE Atlantic. Progress in Oceanography, 166, 139-147. https://doi.org/10.1016/j. pocean.2017.08.005

Bode, A., Carrera, P., \& Lens, S. (2003). The pelagic foodweb in the upwelling ecosystem of Galicia (NW Spain) during spring: Natural abundance of stable carbon and nitrogen isotopes. ICES Journal of Marine Science, 60(1), 11-22. https://doi.org/10.1006/jmsc.2002.1326

Bouillon, S., \& Boschker, H. T. S. (2006). Bacterial carbon sources in coastal sediments: A cross-system analysis based on stable isotope data of biomarkers. Biogeosciences, 3(2), 175-185. https://doi. org/10.5194/bg-3-175-2006 
Burrel, D. C. (1988). Carbon flow in fjords. Oceanography and Marine Biology: An Annual Review, 26, 143-226.

Carstensen, J., Conley, D. J., \& Müller-Karulis, B. (2003). Spatial and temporal resolution of carbon fluxes in a shallow coastal ecosystem, the Kattegat. Marine Ecology Progress Series, 252, 35-50. https://doi. org/10.3354/meps252035

Casini, M., Cardinale, M., \& Arrhenius, F. (2004). Feeding preferences of herring (Clupea harengus) and sprat (Sprattus sprattus) in the southern Baltic Sea. ICES Journal of Marine Science, 61(8), 1267-1277. https:// doi.org/10.1016/j.icesjms.2003.12.011

Connolly, R. M., Guest, M. A., Melville, A. J., \& Oakes, J. M. (2004). Sulfur stable isotopes separate producers in marine food-web analysis. Oecologia, 138(2), 161-167. https://doi.org/10.1007/ s00442-003-1415-0

Darnell, R. M. (1961). Trophic spectrum of an Estuarine Community, based on studies of Lake Pontchartrain, Louisiana. Ecology, 42(3), 553-568. https://doi.org/10.2307/1932242

Davenport, S. R., \& Bax, N. J. (2002). A trophic study of a marine ecosystem off southeastern Australia using stable isotopes of carbon and nitrogen. Canadian Journal of Fisheries and Aquatic Sciences, 59(3), 514-530. https://doi.org/10.1139/f02-031

Duffill Telsnig, J. I., Jennings, S., Mill, A. C., Walker, N. D., Parnell, A. C., \& Polunin, N. V. C. (2018). Data from: Estimating contributions of pelagic and benthic pathways to consumer production in coupled marine food webs. Dryad Digital Repository, https://doi.org/10.5061/ dryad.j6m2267

France, R. (1995). Carbon-13 enrichment in benthic compared to planktonic algae:foodweb implications. Marine Ecology Progress Series, 124(1-3), 307-312. https://doi.org/10.3354/meps124307

Fry, B. (2006). Stable isotope ecology. Berlin, Germany: Springer. https:// doi.org/10.1007/s10764-012-9582-7.Fry

Garrido, S. (2003). Alimentação de Sardina pilchardus (Walbaum,1792) ao largo da costa continental portuguesa e implicações da condição nutricional das fêmeas na qualidade dos oócitos (MS thesis). Instituto de Ciências Biomédicas de Abel Salazar (ICBAS), Porto.

Garrido, S., Marçalo, A., Zwolinski, J., \& Van der Lingen, C. (2007). Laboratory investigations on the effect of prey size and concentration on the feeding behaviour of Sardina pilchardus. Marine Ecology Progress Series, 330, 189-199. https://doi.org/10.3354/ meps330189

Giraldo, C., Ernande, B., Cresson, P., Kopp, D., Cachera, M., Travers-Trolet, M., \& Lefebvre, S. (2017). Depth gradient in the resource use of a fish community from a semi-enclosed sea. Limnology and Oceanography, 62(5), 2213-2226. https://doi.org/10.1002/Ino.10561

Graf, G. (1992). Benthic-pelagic coupling - A benthic view. Oceanography and Marine Biology, 30, 149-190.

Hargrave, B. T. (1973). Coupling carbon flow through some pelagic and benthic communities. Journal of the Fisheries Research Board of Canada, 30(9), 1317-1326. https://doi.org/10.1139/f73-212

Heessen, H. J. L., Daan, N., \& Ellis, J. R. (2015). Fish Atlas of the Celtic Sea, North Sea and Baltic Sea: Based on international research vessel data. Zeist, the Netherlands: KNNV Publishing. https://doi. org/10.3920/978-90-8686-878-0

ICES. (2016). Database of Trawl Surveys (DATRAS), Extraction 20-05-2016. International Bottom Trawl Survey (IBTS) data 2006. Copenhagen, Denmark: ICES. http://datras.ices.dk

Jennings, S., \& Cogan, S. M. (2015). Nitrogen and carbon stable isotope variation in northeast Atlantic fishes and squids. Ecology, 96(9), 2568-2568. https://doi.org/10.1890/15-0299.1

Jennings, S., D'Oliveira, J. A. A., \& Warr, K. J. (2007). Measurement of body size and abundance in tests of macroecological and food web theory. Journal of Animal Ecology, 76(1), 72-82. https://doi. org/10.1111/j.1365-2656.2006.01180.x

Jennings, S., \& van der Molen, J. (2015). Trophic levels of marine consumers from nitrogen stable isotope analysis: Estimation and uncertainty.
ICES Journal of Marine Science: Journal Du Conseil, 72(8), 2289-2300. https://doi.org/10.1093/icesjms/fsv120

Jumars, P. (2007). Habitat coupling by mid-latitude, subtidal, marine mysids. Oceanography and Marine Biology, 45, 89-138. https://doi. org/10.1201/9781420050943.ch3

Jumars, P. A., Dorgan, K. M., \& Lindsay, S. M. (2015). Diet of worms emended: An update of polychaete feeding guilds. Annual Review of Marine Science, 7(1), 497-520. https://doi.org/10.1146/ annurev-marine-010814-020007

Kiørboe, T., Lundsgaard, C., Olesen, M., \& Hansen, J. L. S. (1994). Aggregation and sedimentation processes during a spring phytoplankton bloom: A field experiment to test coagulation theory. Journal of Marine Research, 52(2), 297-323. https://doi. org/10.1357/0022240943077145

Kopp, D., Lefebvre, S., Cachera, M., Villanueva, M. C., \& Ernande, B. (2015). Reorganization of a marine trophic network along an inshore-offshore gradient due to stronger pelagic-benthic coupling in coastal areas. Progress in Oceanography, 130, 157-171. https://doi. org/10.1016/j.pocean.2014.11.001

Kürten, B., Painting, S. J., Struck, U., Polunin, N. V. C., \& Middelburg, J. J. (2013). Tracking seasonal changes in North Sea zooplankton trophic dynamics using stable isotopes. Biogeochemistry, 113(1-3), 167-187. https://doi.org/10.1007/s10533-011-9630-y

Le Loc'h, F., Hily, C., \& Grall, J. (2008). Benthic community and food web structure on the continental shelf of the Bay of Biscay (North Eastern Atlantic) revealed by stable isotopes analysis. Journal of Marine Systems, 72(1-4), 17-34. https://doi.org/10.1016/j. jmarsys.2007.05.011

Lehane, C., \& Davenport, J. (2002). Ingestion of mesozooplankton by three species of bivalve; Mytilus edulis, Cerastoderma edule and Aequipecten opercularis. Journal of the Marine Biological Association of the UK, 82(4), 615-619. https://doi.org/10.1017/S0025315402005957

Levinton, J., \& Kelaher, B. (2004). Opposing organizing forces of deposit-feeding marine communities. Journal of Experimental Marine Biology and Ecology, 300(1-2), 65-82. https://doi.org/10.1016/j. jembe.2003.12.008

Magozzi, S., Yool, A., Vander Zanden, H. B., Wunder, M. B., \& Trueman, C. N. (2017). Using ocean models to predict spatial and temporal variation in marine carbon isotopes. Ecosphere, 8(5), e01763. https://doi. org/10.1002/ecs2.1763

Marcus, N. H., \& Marcus, N. H. (1998). Minireview: The importance of benthic-pelagic coupling and the forgotten role of life cycles in coastal aquatic systems. Limnology and Oceanography, 43(5), 763768. https://doi.org/10.4319/lo.1998.43.5.0763

Marsay, C. M., Sanders, R. J., Henson, S. A., Pabortsava, K., Achterberg, E. P., \& Lampitt, R. S. (2015). Attenuation of sinking particulate organic carbon flux through the mesopelagic ocean. Proceedings of the National Academy of Sciences of the United States of America, 112(4), 1089-1094. https://doi.org/10.1073/pnas.1415311112

Mauchline, J. (1980). The biology of mysids and euphausiids. Advances in Marine Biology, 18, 1-677.

Mauchline, J. (1982). The predation of mysids by fish of the Rockall Trough, northeastern Atlantic Ocean. Hydrobiologia, 93(1-2), 85-99. https://doi.org/10.1007/BF00008102

McCann, K. S., Rasmussen, J. B., \& Umbanhowar, J. (2005). The dynamics of spatially coupled food webs. Ecology Letters, 8(5), 513-523. https://doi.org/10.1111/j.1461-0248.2005.00742.x

Michener, R. H., \& Kaufman, L. (2007). Stable isotope ratios as tracers in marine food webs: An update. In K. Michener \& R. Lajtha (Eds.), Stable isotopes in ecology and environmental science (2nd ed., pp. 238-282). Oxford, UK: Blackwell Publishing Ltd. https://doi. org/10.1002/9780470691854.ch9

Middelburg, J. J. (2014). Stable isotopes dissect aquatic food webs from the top to the bottom. Biogeosciences, 11(8), 2357-2371. https://doi. org/10.5194/bg-11-2357-2014 
Moore, J. C., Berlow, E. L., Coleman, D. C., Ruiter, P. C., Dong, Q., Hastings, A., ... Wall, D. H. (2004). Detritus, trophic dynamics and biodiversity. Ecology Letters, 7(7), 584-600. https://doi. org/10.1111/j.1461-0248.2004.00606.x

Mussap, G., \& Zavatarelli, M. (2017). A numerical study of the benthicpelagic coupling in a shallow shelf sea (Gulf of Trieste). Regional Studies in Marine Science, 9, 24-34. https://doi.org/10.1016/j. rsma.2016.11.002

Noji, T. T., Noji, C. I.-M., \& Barthel, K.-G. (1993). Pelagic-benthic coupling during the onset of winter in a northern Norwegian fjord. Carbon flow and fate of suspended particulate matter. Marine Ecology Progress Series, 93, 89-99. https://doi.org/10.3354/meps093089

Norén, F., Haamer, J., \& Lindahl, O. (1999). Changes in the plankton community passing a Mytilus edulis mussel bed. Marine Ecology Progress Series, 191, 187-194. https://doi.org/10.3354/meps191187

Parnell, A. C. (2016). simmr. Retrieved from https://cran.r-project.org/ web/packages/simmr/index.html

Parnell, A. C., Inger, R., Bearhop, S., \& Jackson, A. L. (2010). Source partitioning using stable isotopes: Coping with too much variation. PLoS ONE, 5(3), e9672. https://doi.org/10.1371/journal.pone.0009672

Parnell, A. C., Phillips, D. L., Bearhop, S., Semmens, B. X., Ward, E. J., Moore, J. W., ... Inger, R. (2013). Bayesian stable isotope mixing models. Environmetrics, 24(6), 387-399. https://doi.org/10.1002/ env. 2221

Petitgas, P. (Ed.). (2010). Life cycle spatial patterns of small pelagic fish in the Northeast Atlantic. ICES Cooperative Research Report, No. $306,93 \mathrm{pp}$.

Pinnegar, J. K. (2014a). DAPSTOM - An integrated database \& portal for fish stomach records. Cefas contract report: DP332, C3746, ME1228.

Pinnegar, J. K. (2014b). DAPSTOM - An integrated database \& portal for fish stomach records. Version 4.7. Lowestoft, UK: Centre for Environment, Fisheries \& Aquaculture Science. February 2014, 39 pp. https:// www.cefas.co.uk/cefas-data-hub/fish-stomach-records/

Polunin, N. V. C., \& Pinnegar, J. K. (2002). Trophic ecology and the strucutre of marine food webs. In P. J. B. Hart \& J. C. Reynolds (Eds.), Handbook of fish and fisheries (Vol. 1). Oxford, UK: Blackwell.

Post, D. M., Layman, C. A., Arrington, D. A., Takimoto, G., Quattrochi, J., \& Montaña, C. G. (2007). Getting to the fat of the matter: Models, methods and assumptions for dealing with lipids in stable isotope analyses. Oecologia, 152(1), 179-189. https://doi.org/10.1007/ s00442-006-0630-x

Reecht, Y., Rochet, M.-J., Trenkel, V. M., Jennings, S., \& Pinnegar, J. K. (2013). Use of morphological characteristics to define functional groups of predatory fishes in the Celtic Sea. Journal of Fish Biology, 83(2), 355-377. https://doi.org/10.1111/jfb.12177

Ringelberg, J. (2010). Diel vertical migration of zooplankton in lakes and oceans. Dordrecht, the Netherlands: Springer. https://doi. org/10.1007/978-90-481-3093-1

Ruardij, P., \& Van Raaphorst, W. (1995). Benthic nutrient regeneration in the ERSEM ecosystem model of the North Sea. Netherlands Journal of Sea Research, 33(3-4), 453-483. https://doi. org/10.1016/0077-7579(95)90057-8

Scharf, F., Juanes, F., \& Rountree, R. A. (2000). Predator size-prey size relationships of marine fish predators: Interspecific variation and effects of ontogeny and body size on trophic-niche breadth. Marine Ecology Progress Series, 208, 229-248. https://doi.org/10.3354/ meps208229

Silva, J. F., Ellis, J. R., \& Ayers, R. A. (2013). Length-weight relationships of marine fish collected from around the British Isles. Science Series Technical Report, Cefas Lowestoft (Vol. 150).

Somes, C. J., Schmittner, A., Galbraith, E. D., Lehmann, M. F., Altabet, M. A., Montoya, J. P., ... Eby, M. (2010). Simulating the global distribution of nitrogen isotopes in the ocean. Global Biogeochemical Cycles, 24(4), 1-16. https://doi.org/10.1029/2009GB003767
Sparholt, H. (1990). An estimate of the total biomass of fish in the North Sea. Journal Du Conseil, Conseil International Pour l'Exploration de La Mer, 46, 200-210. https://doi.org/10.1093/icesjms/46.2.200

Steele, J., \& Collie, J. (2005). Functional diversity and stability of coastal ecosystems. In The Sea (Vol.13, pp. 783-817). Cambridge, MA: Harvard University Press.

Su, Y.-S., \& Yajima, M. (2015). R2jags: Using R to Run "JAGS." Retrieved from https://cran.r-project.org/package=R2jags

Suess, E. (1980). Particulate organic carbon flux in the oceans-surface productivity and oxygen utilization. Nature, 288(5788), 260-263. https://doi.org/10.1038/288260a0

Sweeting, C. J., Barry, J., Barnes, C., Polunin, N. V. C., \& Jennings, S. (2007). Effects of body size and environment on diet-tissue $\delta 15 \mathrm{~N}$ fractionation in fishes. Journal of Experimental Marine Biology and Ecology, 340(1), 1-10. https://doi.org/10.1016/j.jembe.2006.07.023

Sweeting, C. J., Barry, J. T., Polunin, N. V. C., \& Jennings, S. (2007). Effects of body size and environment on diet-tissue $\delta 13 \mathrm{C}$ fractionation in fishes. Journal of Experimental Marine Biology and Ecology, 352(1), 165-176. https://doi.org/10.1016/j.jembe.2007.07.007

Sweeting, C. J., Polunin, N. V. C., \& Jennings, S. (2006). Effects of chemical lipid extraction and arithmetic lipid correction on stable isotope ratios of fish tissues. Rapid Communications in Mass Spectrometry, 20(4), 595-601. https://doi.org/10.1002/rcm.2347

Telsnig, J. (2018). jtelsnig/Duffill-Telsnig-et-al-2018: First release (Version V1.0). Zenodo. https://doi.org/10.5281/zenodo.1476659

Thode, H. (1991). Sulfur isotopes in nature and the environment: An overview. In H. Krouse \& V. Grinenko (Eds.), Stable isotopes: Natural and anthropogenic sulphur in the environment (pp. 1-26). Chichester, UK: Wiley.

Vedel, A. (1998). Phytoplankton depletion in the benthic boundary layer caused by suspension-feeding Nereis diversicolor (Polychaeta): grazing impact and effect of temperature. Marine Ecology Progress Series, 171, 125-132. https://doi.org/10.3354/meps171125

Wainright, S. C., \& Fry, B. (1994). Seasonal variation of the stable isotopic compositions of coastal marine plankton from Woods Hole Massachusetts and georges bank. Estuaries, 17(3), 552. https://doi. org $/ 10.2307 / 1352403$

Walker, N. D., Maxwell, D. L., Le Quesne, W. J. F., \& Jennings, S. (2017). Estimating efficiency of survey and commercial trawl gears from comparisons of catch-ratios. ICES Journal of Marine Science, 74(5), 1448-1457. https://doi.org/10.1093/icesjms/fsw250

Wickham, H. (2011). The split-apply-combine strategy for data analysis. Journal of Statistical Software, 40(1), 1-29. Retrieved from http:// www.jstatsoft.org/v40/i01/

Woodland, R. J., \& Secor, D. H. (2013). Benthic-pelagic coupling in a temperate inner continental shelf fish assemblage. Limnology and Oceanography, 58(3), 966-976. https://doi.org/10.4319/lo.2013.58.3.0966

\section{SUPPORTING INFORMATION}

Additional supporting information may be found online in the Supporting Information section at the end of the article.

How to cite this article: Duffill Telsnig Jl, Jennings S, Mill AC, Walker ND, Parnell AC, Polunin NVC. Estimating contributions of pelagic and benthic pathways to consumer production in coupled marine food webs. J Anim Ecol. 2019;88:405-415. https://doi.org/10.1111/1365-2656.12929 